\title{
TRITIUM TRACER MOVEMENT AS AN ANALOGY FOR PUMP AND TREAT REMEDIATION
}

December 1994

NOTICE This document contains information of a preliminary nature. It is subject to revision or correction and therefore does not represent a final report.

Prepared by the

Environmental Sciences Division

Oak Ridge National Laboratory

ESD Publication No. 4370

\section{OAK RIDGE NATIONAL LABORATORY}

Oak Ridge, Tennessee 37831-6352 managed by

MARTIN MARIETTA ENERGY SYSTEMS, INC. for the

U.S. Department of Energy

under contract DE-AC05-84OR21400 


\section{DISCLAIMER}

This report was prepared as an account of work sponsored by an agency of the United States Government. Neither the United States Government nor any agency thereof, nor any of their employees, make any warranty, express or implied, or assumes any legal liability or responsibility for the accuracy, completeness, or usefulness of any information, apparatus, product, or process disclosed, or represents that its use would not infringe privately owned rights. Reference herein to any specific commercial product, process, or service by trade name, trademark, manufacturer, or otherwise does not necessarily constitute or imply its endorsement, recommendation, or favoring by the United States Government or any agency thereof. The views and opinions of authors expressed herein do not necessarily state or reflect those of the United States Government or any agency thereof. 


\section{DISCLAIMER}

Portions of this document may be illegible in electronic image products. Images are produced from the best available original document. 


\section{Interest in pump and treat remediation}

There has been debate over effectiveness of groundwater pump and treat remediation. The goal of the following discussion is to present evidence from a tracer test that illustrates the difficulty in removing contaminants from fractured shale that is typical of portions of the DOE-Oak Ridge Reservation (ORR). This report provides a brief prelude to more detailed analysis that is in progress.

Attempts to remediate groundwater contamination with pump and treat technology have been hampered by difficulties in removing contaminants in slow flow zones. There is interest in using this remediation method on the ORR because it is an existing technology. However, this setting provides a rather extreme contrast between fast flow zones (fractures) and slow flow zones (the matrix surrounding the fractures).

Over the past few years, we have begun to develop an understanding of how contaminants move in fractures and how contaminant exchange between the fracture and matrix occurs. In particular, we have evidence from a long term tritium tracer test that has direct bearing on potential success or failure of pump and treat remediation in fractured rocks.

\section{Tritium tracer test in fractured rock, Oak Ridge Reservation}

In July 197750 curies of tritium were released as a one-time slug in an open borehole at about $7.5 \mathrm{~m}$ depth. then monitored in downgradient monitoring wells $3.6 \mathrm{~m}$ distant. The experiment took place near Waste Area Grouping 4 in Melton Valley under the supervision of the U.S. Geological Survey (USGS). Tritium was monitored by the USGS in the injection well and in seven downgradient weils for 5 years. A follow up sampling occurred in 1993. Details of the experiment and monitoring will be reported elsewhere (David Webster, personal communication, December 1994); this summary is only an abstract of relevant data.

The tracer showed characteristics of both the fast (fracture) and slow (matrix) flow paths (Fig. 1). The first appearance of tritium was fast -- within 21 days with a transport rate of $0.1 \mathrm{~m} /$ day. However, this initial breakthrough represented just a small amount of the total tritium. The bulk of mass travelled at $0.002 \mathrm{~m} /$ day. After the first appearance of tritium, the tracer developed a persistent, low concentration plume that can still be detected 16 years after injection (GWPO, 1994).

These tritium levels have persisted in spite of 100's of borehole volumes that have flushed through the wells for many years -- a sort of natural gradient pumping system. The decline and persistence of tritium, which has also been observed for contaminants in the waste areas, is likely due to slow movement of the large reservoir of tritium in the matrix. The initial rapid appearance of tritium is believed to be due to fracture flow.

\section{Failure of pumping to "remediate" tritium tracer}

Approximately 200 days after the injection of the tritium, an attempt was made to remove the remaining tracer from the injection well to try to shorten the duration of the test. On several occasions over a period of weeks, tritiated water was removed from the injection well and simultaneously replaced with clean groundwater to reduce the tritium concentrations roughly an order of magnitude. Each time, tritium levels returned to pre-treatment concentrations. It was finally concluded that the attempts to remove tritium were not effective and had no impact on the experiment (Fig. 2). Based on current knowledge, it can be concluded that matrix diffusion was controlling the amount of tritium that could be removed, and the inventory of tritium in the rock matrix was not amenable to effective removal by pumping. 
4. Implications for failure of pump and treat

Pumping failed to remove the tritium because only the tritium in the well and in the fast flow zones could be removed. Significant amounts of water and contaminants will not be removed from the slow flow zones by pumping or natural flow because only the fractures are flushed, not the matrix.

This experiment presented an optimal case for source removal on the ORR because the shallow zone is highly fractured and is more likely than deeper zones to behave as a porous rather than a fractured medium. However. conventional pump and treat will fail as a plume remediation technology in fractured rock because the matrix has become a long term secondary source of contaminants (e.g., long tail in Fig. 2). The long time and high costs of removal in this setting make it impractical. The use of pump and treat to contain contamination and prevent continued spreading (source control rather than source removal) may hold promise if done properly.

This experiment confirms recent evidence pointing to the importance of the matrix in contaminant movement and persistence on the Oak Ridge Reservation (Wilson et al., 1993, Sanford et al., 1994, Wickliff et al., 1991). At present. work is underway to quantify the effects of secondary sources through modeling and field experiments to provide technically sound estimates of time needed to reach remediation goals (GWPO, 1994). It is recommended that a combination of methods be used for source control, but that source removal from the matrix is not a viable option using pumping.

\section{References}

GWPO, 1994. Ground Water Program Office Annual Report for Fiscal Year 1994. ORNL/GWPO-013.

Sanford, W.E., P.M. Jardine. D.K Solomon, Examining matrix diffusion in fractured shales with noble gases, Geol. Soc. of Am. Abstracts with Programs, 26, p. A-362, Seattle Washington, Oct. 24-27, 1994.

Wilson, G.V., P.M. Jardine, J.D. O'Dell, and M. Collineau, Field-scale transport from a buried line source in variably saturated soil. J. Hydrol. 145, pp. 83-109, 1993.

Wickliff, D.S., Solomon. D.K. N.D. Farrow, Preliminary investigation of processes that affect source term identification, ORNL/ER-59, 31 pp., 1991. 

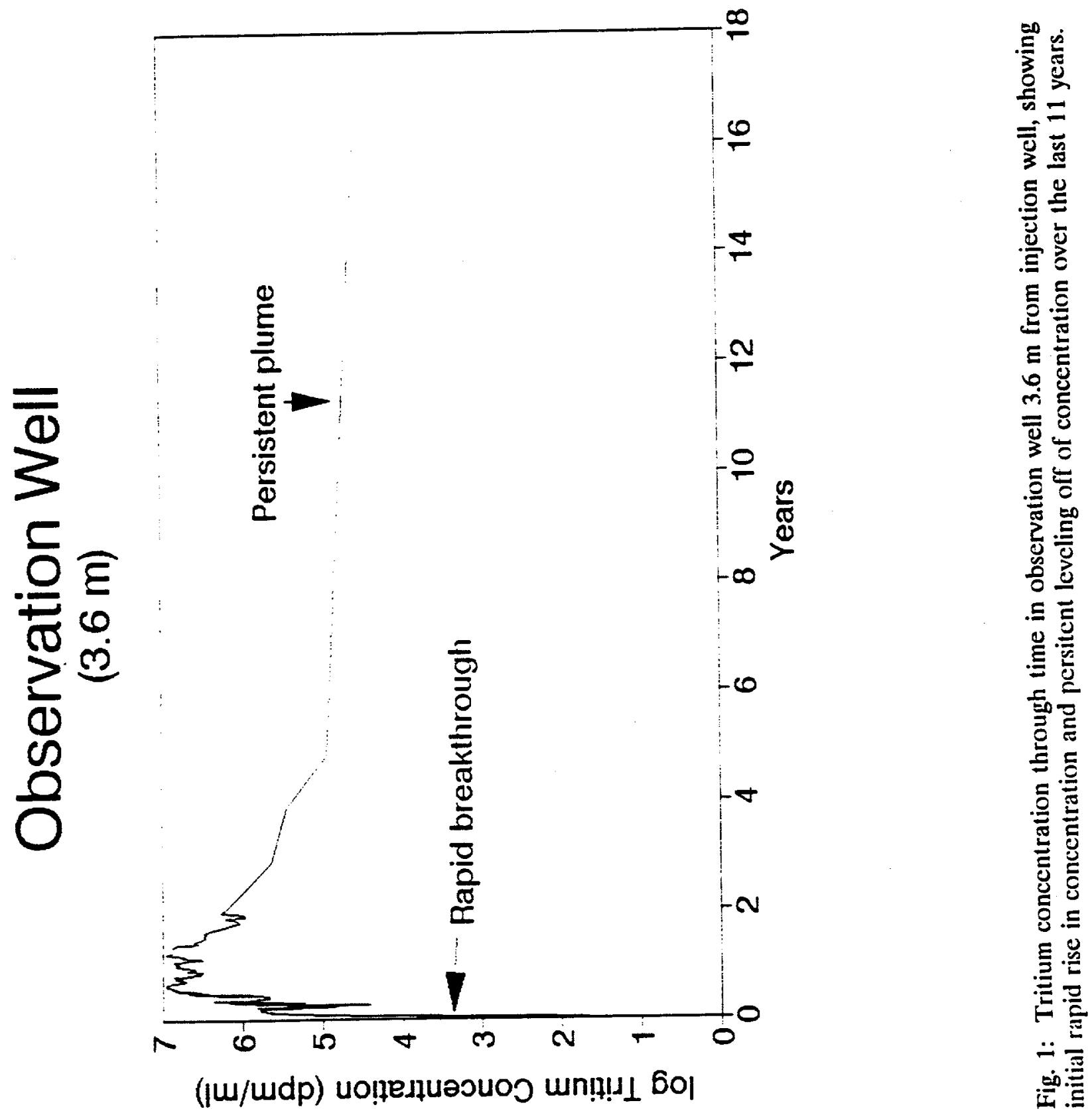


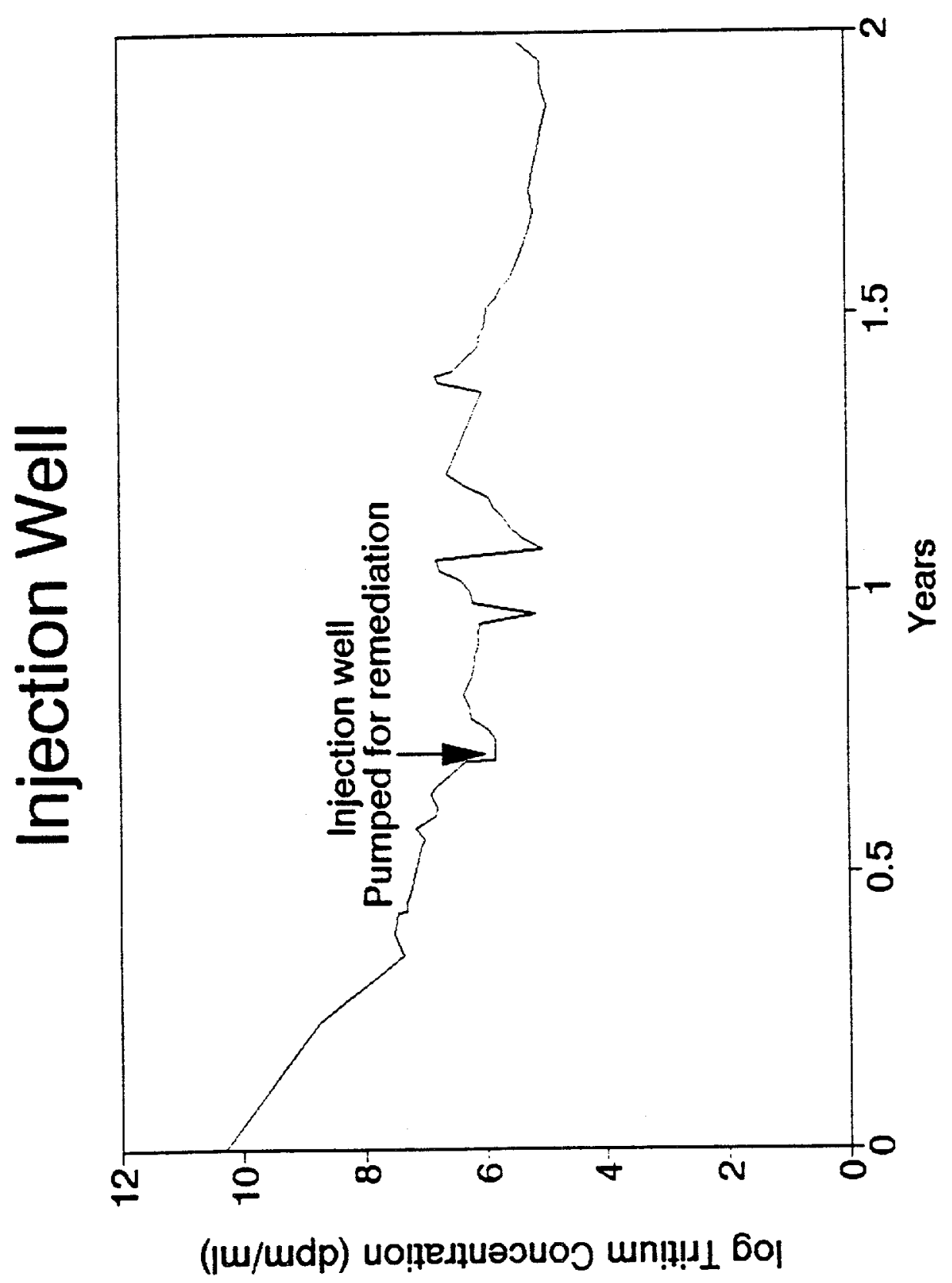

$\stackrel{Ð}{=}$

몰

б

巳ัٌ

$\stackrel{\varrho}{E}$

ळ

ธิ

己ِّ

E巳

$\stackrel{\Xi}{ }$

.

늘

D

ก

起

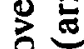

ธิ

Е.

ป

ธี

E

E

온

त

运 


\section{INTERNAL DISTRIBUTION}

1. F. A. Anderson

2. L. V. Asplund

3. P. E. Barndt

4. R. O. Barnett

5. L. D. Bates

6. F. P. Baxter

7. D. T. Bell

8. H. L. Boston

9. R. B. Clapp

10. K. W. Cook

11. T. K. Cothron

12. J. H. Cushman

13. F. P. Delozier

14. A. Diefendorf

15. R. B. Dreier

16. T. O. Early

17. J. M. Forstrom

18. D. E. Fowler

19. C. W. Gehrs

20. P. A. Gourieux
21. J. T. Grumski

22. C. S. Haase

23. S. G. Hildebrand

24. D. D. Huff

25. G. K. Jacobs

26. W. K. Jago

27. K. G. Kahl

28. P. Kanciruk

29. R. H. Ketelle

30. H. L. King

31. A. J. Kuhaida

32. G. R. Miller

33. G. R. Moline

34. G. K. Moore

35. C. A. Motley

36. J. B. Murphy

37. M. J. Norris

38. R. S. Poling

39. D. E. Reichle

40. C. T. Rightmire
41. T. H. Row

42. W. E. Sanford

43. F. E. Sharples

44. D. S. Shriner

45. E. D. Smith

46. S. H. Stow

47. L. E. Toran

48. L. O. Vaughan

49. D. B. Watson

50. S. H. Welch

51. R. K. White

52. S. L. Winters

53. T. F. Zondlo

54. Central Research Library 55-69. ESD Library

70. Laboratory Records Dept.

71. Laboratory Records, ORNL-RC

72. ORNL Patent Section

73. ORNL Y-12 Technical Library

\section{EXTERNAL DISTRIBUTION}

74. Benfield, Tennessee Department of Environmental Conservation, U.S. Department of Energy Oversite Office, 761 Emory Valley Road, Oak Ridge, TN 37831

75. G. W. Bodenstein, U.S. Department of Energy, Oak Ridge Operations Office, IRC Buidling, P.O. Box 2001, Oak Ridge, TN 37838-8541

76. P. Craig, Environmental Consulting Engineers, Inc., P.O. Box 22668, Knoxville, TN 37933

77. E. K. Evans, Jacobs Engineering, 125 Broadway Avenue, Oak Ridge, TN 37831

78. R. N. Farvolden, Professor, Department of Earth Sciences, University of Waterloo, Waterioo, Ontario N2L 3G1 Canada

79. D. W. Freckman, Director, College of Natural Resources, 101 Natural Resources Building, Colorado State University, Fort Collins, CO 80523

80. R. C. Harriss, Institute for the Study of Earth, Oceans, and Space, Science and Engineering Research Building, University of New Hampshire, Durham, NH 03824

81. B. Jenks, CDM Federal, 800 Oak Ridge Turnpike, Suite 500, Oak Ridge, TN 37830 
82. S. W. Jones, Tennessee Department of Environmental Conservation, U.S. Department of Energy Oversite Office, 761 Emory Valley Road, Oak Ridge, TN 37831

83. G. Y. Jordy, Director, Office of Program Analysis, Office of Energy Research, ER-30, G-266, U.S. Dpeartment of Energy, Washington, DC 20545

84. Larry D. McKay, University of Tennessee, Department of Geology, 306 G\&G Building, Knoxville, TN 37996-1410

85. D. P. Moss, SAID, 800 Oak Ridge Turnpike, P.O. Box 2502, Oak Ridge, TN 37831

86. R. H. Olsen, Professor, Microbiology and Immunology Department, University of Michigan, Medical Sciences II, \#5605, 1301 East Catherine Street, Ann Arbor, MI 481090620

87. J. P. Ottinger, Tennessee Department of Environmental Conservation, U.S. Department of Energy Oversite Office, 761 Emory Valley Road, Oak Ridge, TN 37831

88. A. Patrinos, Director, Environmental Sciences Division, Office of Health and Environmental Research, ER-74, U.S. Department of Energy, Washington, DC 20585

89. S. P. Riddle, U.S. Department of Energy, Oak Ridge Operations Office, IRC Buidling, P.O. Box 2001, Oak Ridge, TN 37838-8541

90. R. C. Sleeman, U.S. Department of Energy, Oak Ridge Operations Office, IRC Buidling, P.O. Box 2001, Oak Ridge, TN 37838-8541

91. D. K. Solomon, Department of Geology and Geophysics, 717 W. C. Browning Building, Salt Lake City, UT 84112-1183

92. D. A. Webster, U.S. Geological Survey, 810 Broadway, Suite 500, Nashville, TN 37203

93. F. J. Wobber, Environmental Sciences Division, Office of Health and Environmental Research, ER-74, U.S. Department of Energy, Washington, DC 20585

94-95. Office of Assistant Manager for Energy Research and Development, U.S. Department of Energy Oak Ridge Operations, P.O. Box 2001, Oak Ridge, TN 37831-8600

96-97. Office of Scientific and Technical Information, P.O. Box 62, Oak Ridge, TN 37831 